\title{
Endonuclease III-Like Protein 1
}

National Cancer Institute

\section{Source}

National Cancer Institute. Endonuclease III-Like Protein 1. NCI Thesaurus. Code C106194.

Endonuclease III-like protein 1 (312 aa, $\sim 34 \mathrm{kDa}$ ) is encoded by the human NTHL1 gene. This protein plays a role in nucleotide-excision repair. 